\title{
Cosmic Signs in the Poetry of Kadare
}

\author{
Merxhan Avdyli ${ }^{1}$ \\ ${ }^{1}$ Public University "Kadri Zeka" Gjilan, Republic of Kosovo \\ Correspondence: Merxhan Avdyli, Prof. Ass. PhD., Faculty of Education, Public University "Kadri Zeka" Gjilan, \\ Republic of Kosovo. E-mail: merxhan.avdyli@uni-gjilan.net
}

Received: November 22, 2019; Accepted: December 9, 2019; Published: April 1, 2020

\begin{abstract}
This paper deals with the cosmic signs displayed in the poetry of one of the best Albanian writers, Ismail Kadare. By highlighting the way Kadare's cosmic poetry is dealt with, namely by distinguishing his poems, we will essentialize through an analysis until a sublimated synthesis the main signs presented in Kadare's poetic lexicon.

Since Kadare's poetry is also distinguished through a fundamental element of its construction - the word, we will undertake such a study adventure, to see how different words, different concepts, different thoughts and ideas are presented. with some of the cosmic signs used by Kadare such as: sun, moon, star, sky, earth.
\end{abstract}

Keywords: poetry, Kadare, signs, cosmos, treatment, sun, moon, star, sky, earth

\section{Introduction}

In this way it should be explained that cosmic signs here will not only be treated as signs in the sense of the symbol, though they also have symbols, as well as signs in the Saussure's sense, (Note 1) but they will be treated as distinctive signs, as distinctive signs in poetry. Kadare's works, which make his poetry not only more special by their marking, but also more characteristic in distinguishing its quality, more complete and more realized in all its constructive and reflective dimensions.

Likewise, one has to dwell on another fact regarding the sign. Well-known literary theorists Oswald Ducrot and Tzvetan Todorov, treating the sign, in the sense that we treat it, as they regard it as the basic notion of any science of discourse, recognize the difficulty of defining it. (Osvald, D., Tzvetan, T., \& Fjalor, 1984) Perhaps, after differentiating the sign from the symbol, the difficulties of understanding would also be alleviated.

We find it valuable to emphasize the relationship between the notion of sign and the notion of symbol, which, although they are similar notions, are not entirely the same. While the sign is a notion that helps build the stylistic figure, in this case the symbol itself, it is nevertheless not a stylistic figure as is traditionally the symbol.

In another sense we will also try to clarify the use of the sign, in the sense of the Saussure's sign (Note 1) according to which every word is a sign, whereas in this monograph, as we have used this concept, the sign is a separate word from the group of words, precisely because of its role and function, as well as the other particular structural and emotional hues it receives in the poetic text. In this sense the notion of sign, although it may have similarities, is clearly distinguished from the key word, which is a key word of a text.

Thus, based on the notion of the sign, in the sense differentiated from the symbol and the key word, as a lecturing and lexical unit, which in this way can sometimes be equivalent to the symbol or simply a meaning which make the meaning of poetic discourse easier to understand, we will try to understand and treat the sign as a sign that is singled out in the poetic lexicon of Ismail Kadare's poetry.

\section{Treatment of Poetic Signs with Aesthetic Effects}

Cosmic signs occupy a deserved place in Ismail Kadare's poetry. Although they are of great and widespread use, we will present and address only those which we consider to be more substantive and functional and which complement the artistic and aesthetic effects of Kadare's poetry which are in function of aquiline symbol or aquiline stylistic figure.

In this respect we will treat the cosmic signs, which often in Kadare's poetry come to us with different layers and subdivisions, even as special symbols, namely as meanings which raise the level of his poetry to a certain level. Properly literary, artistic and aesthetic, how are the signs: sun, moon, star, sky and earth, which are not the only cosmic signs that Kadare uses. Because in his poetry there are other cosmic signs, where they are more often and 
less frequently used in various functions, whether motivational or symbolic, or complementary to the full realization of poetry.

The cosmic signs in Kadare's poetry play their part, regardless of the poetic idea, theme or motif. Because these signs perform their function, as in patriotic poetry, love poetry, or other motifs. In fact, one of Kadare's collections of poetry is entitled, precisely because of the use of one of the cosmic signs, in this case the sun. It is about the poetry book Sunny Motives.

\section{The Sun (Light, Warmth, Vibrancy)}

We have already pointed out above that exactly one of Kadare's poetic works, in its title, stands out as the sun sign - the collection "Sunny Motives". The book in question received the title from the poem of the same title, "Sunny Motives", which is an exhilarating display of views of the Lura Lakes in the evening and a reflection of the author's concerns about the evening fall in the Lura Lakes, with where does he suggest the lyric hero, addressing:

He grabs a handful of colors that vibrate and glisten

Fleeing alarmingly from the evening that follows.

Captures sunny motifs...

Never brush the night through your brush. (Ismail Kadare \& Motive, 1978)

The sun is one of the main cosmic signs that he uses in his Kadare poetry, even in different meanings. In this way, Kadare sometimes uses the sun as an identification with the homeland, sometimes as something that brings warmth to mankind. But there are times when the sun also uses it in other ways, as identifying and personifying, to compare any personality with it.

The dimensions of the Kadare sun are very large because in most cases size is the main element by which one compares one or something to the sun. And, in such cases, in addition to the metaphor and comparison figure, hyperbole is also used. The sun at Kadare often comes out as an illuminating epicenter, respectively, as an antipode of darkness and evil. Indeed, there are times when the sun is used to show scientific and technical knowledge, which has also influenced the decay of poetry, as Kadare says in poetry "Poetry and Technique":

Sun eclipse found, whatever. (Ismail Kadare \& Koha, 1976)

The sun sign, even when not used as a symbol, is used to create interesting images, images that we seem to have in front of our eyes and that at the same time seem to us to be easily drawn by Kadare through his lyrical verses, such as eg in the poem "Winter Morning on the Beach", where he compares the sunshine to the shells with the pieces of a broken service:

Saving the winter sun above the shells falls

Like the power bits that accidentally broke. (Ismail Kadare, 1990)

\section{Moon (Little Moon, Contemplation, Beauty, Guard of Love)}

The moon is the sign of others, used in Kadare's poetry, which though as a cosmic sign, appears in the form of a gaze element or even as a symbol, in some cases, and sometimes even as part of the female physique, when compared with any part of the female or as an illuminating and observing element of dating lovers alike. However, the moon appears to a considerable extent in Kadare's poetry, even more prominently than other signs. Some Kadare poems focus on the moon itself, either as a symbol or as a sign that aids or supplements the creation of stylistic figures, as well as the full realization of poetry, such as the poems: "You and the Moon"( Ismail Kadare, 1957) or "The Moon and poplar". (Ismail Kadare, 1976)

The introduction of the moon in the function of poetry is variable, because in almost all the poems where the presence of the moon is the other auxiliary elements, namely the signs or symbols that influence the moon to appear in different places, situations and conditions. different. A fascinating picture, an image where the moon's role is sensitive in association with wild geese and poplars, is found in the poem "Flowers",

\section{Flowerpots under the moonlight}

Fall like brilliance somewhere

The wild goose flew to heaven

With a little moon in the wings too. (Ibidem, p. 7.)

Likewise, we have an even more interesting picture in the short poem in the title of which we have the very sign that we are treating "Moon on Poplar". The poplar hiding the girl's look from the moon was cut by the girl's 
boyfriend, who, however, could not hide from the moon, from where we have her gaze role in this short erotic ballad, as in the verses, as more follows:

\section{The moon above the poplars}

Plates - plates that

You cut the poplar

Yeah, let's go. (Ibidem, p. 63.)

A typical personifying comparison of the beloved female and the moon is in the poem "You and the Moon", which shows the arrival of a girl in the thoughts of a lyrical hero who sometimes appears, sometimes disappears, like the moon hiding behind a cloud, as in verses:

\section{O clouds my thoughts}

I'm being reminded more often

And behind them there is always yours

Like this moon that looks in the middle of a cloud. (Ismail Kadare, 1957)

The moon is used in Kadare's poetry in a slightly more elusive and non-spiritual sense. This mainly happens in those poems that are motivated by our national history, namely in patriotic poetry, since the moon is in this sense understood as an Ottoman symbol. Thus, the moon in this function is in the poem "Portrait of Skanderbeg", where the moon shows a faintness of the name Skënder (Skanderbeg), opposite the solar name Gjergj (George), or in the poem "Arrival of the Imperial Decree",(Ibidem, p. 43.) where we have a balance of crescent lighting (in the meaning of the Ottoman symbol) with the seals "starting to bleed".

Not only as the crescent, where the moon sign takes on negative meanings, but the moon is also used in the form of the moon, which nevertheless illuminates, as in the poem "The Spirit of the Future"( Ismail Kadare, 1954) or even in the poem "The Eagle and the Crescent",( Ismail Kadare, 1990) where we face "A two-headed eagle and a crescent," as Kadare puts it.

\section{Star (Cosmic Star, Symbolic Star)}

The star in Kadare's poetry, like the moon always plays a positive role, is that part of poetry that expresses tenderness, closeness, brightness and love. The star in Kadare's poetry is always radiant, even when it is a function of political poetry, regardless of aesthetic achievement, even when used in comparative function in his lovemotivated poetry. Often the star's sign is correlated with the moon, as two approximate elements of Kadare's poetry with love motifs, as is the case with "Ballad"(Ismail Kadare, 1957) poetry. Even the sign of a star, like the moon, is rarely the focus of a poem as in the poems: "Stars do not just fall",( Ismail Kadare, 1961) "Stars" (Ismail Kadare, 1957) and others.

The star in Kadare's poetry is not infrequently used in the plural, as the stars and their poetic exploits are incorporated into all his poetic motives, even from patriotic poetry to political poetry with revolutionary marks, we would say, but also in love poetry as well as in meditative poetry.

With high functionality, the use of stars is in the poem "Spring", where the star-reflecting soup is put to the test. The verse in which he is a reinforce of the idea of poetry and operationalizing the whole construction of this poetry is:

Only the soup does not reflect the stars. (Ismail Kadare, 1961)

Although in the poem "Spring" the stars are not reflected in the soup, Kadare, as in other editions of this poem, removes, changes and changes the poetic concept of the soup and now puts in front of the stars a much more functional, though darker, not only meaningful and much less reflective of the stars - the scum, giving the variant as follows.

Only the sludge does not reflect the stars. (Ismail Kadare, 2005)

Changing this verse also involves changing the formal aspect of poetry, because in other versions of this poetry this changed verse is no longer a singular one, but is within the second unit of the poem "Spring".

But the stars in Kadare's patriotic poetry take on a different dimension. In poetry of this type, respectively in patriotic poetry, the stars usually relate to the other two concepts - Albania, which sometimes emerges as a homeland and heaven. Such a more realistic connection emerges in the poems "Stars", respectively in the verses:

The endless paths of mother Albania 
With stars above the tombs they twist

As if from heaven you have fallen

On the heads of resting heroes

Many stars have fallen through the clouds. (Ismail Kadare, 1957)

Starlight in Kadare's poetry is also used in meditative poetry and when the star, with its illuminating dimensions, becomes a symbol of another cosmic sign, such as the earth. In this functional connection, the author, speaking the dream, in the poem "Dream", states:

And the earth shone like a star among other stars. (Ibidem, p. 17.)

But stars in a poem, like in the poem "Deer" is an indicator of heights, from where the height of the deer horns is sublimated relative to the height of the stars, as in the verse:

O deer high with those horns with those horns up to the stars. (Ismail Kadare, 1990)

\section{Heaven (Appearance, Shape, Width)}

The sky in Kadare's poetry is ever-changing, but as such, as a cosmic sign, Kadare is very functional, because through it he can create excellent images, create moments and situations of various kinds, even not least absurd situations and paradoxes. Not only the darkness of the real, as well as the actual sky, but also its real, as well as the actual sobriety, in Kadare's poetry constantly raise various issues, linking factual situations with those of artistic imagination.

The sign of heaven influenced Kadare's selective collection to be called Formless is the sky, which is at the same time the first part of the first verse and the first part of the last verse of the poem "Autumn Tyrant", supplemented with the part "like an idiot's brain", The first verse and with" like an idiot thought"- the last verse. The qualification of this poem, by some scholars as anthologized and emblematic verses, is consistent, but the tendencies to draw from this poem some kind of Kadare's dissidentism towards socialism are not consistent and as such have only influenced it. in expressing unfounded thoughts, even giving the sky of this poetry the dimension of "then socialist heaven", as the scholar Sadik Bejko puts it in the preface to the Selection Poetry Book is the sky. (Note 2)

Poetry "Autumn Tyrant" has a complete construction, has a strong connection between what is seen in reality, on a fall day, with the imagination of the author who manages to be aesthetically sublimated through stylistic figures, on this occasion of comparison. It would undoubtedly be necessary the whole picture, even the graphic of poetry:

The sky is without form, like an idiot's brain

Boring sidewalks rain porridge.

A passerby, an umbrella, thunders the weather

A bike twists and turns.

Shapeless is heaven, like an idiot thought. (Ismail Kadare, 2005)

The sky in Kadare's poetry is presented in different forms, with different looks and different functional characteristics.

Thus, in the poem "General Landscape" is presented:

Magnificent, cold and boundless sky. (Ismail Kadare, 1961)

In the poem "Autumn Poem":

The sky bowed

Thousands of water canes

Knocks like a blind old man going away in the night. (Ibidem, p. 12.)

In the poem "Winter Sky", the sky is presented as an inspiration for memories, interesting comparative imagery:

Winter sky

An influx of memories

I lit a cigarette, approached the window.

It looks like there are no snowflakes falling from the sky

But thousands of letters, which I never received. (Ibidem, p. 32.) 
Whereas in the poem "On the Trip", which is a beautiful description of the author, when he departs to his city during winter holidays, he uses the sign heaven through metaphor:

\section{I travel south}

Behind the glass I see the sky above the well. (Ismail Kadare, 1957)

Whereas in the poetry "Cataracts":

Icy, the sky reflects. (Ismail Kadare, 1964)

The sky as a cosmic sign is quite present in Kadare's poetry, being in function of different images, different images, often in conjunction with other cosmic signs such as: sun, earth, stars, etc. Heaven is sometimes used also in the sense of latitude, infinity, respectively in the sense of the universe.

Heaven is also used as a sign of definition, but also of infinity, or even of trekking, as in the poem "Kosovo":

How many times have I passed over your heaven Kosovo. (Ismail Kadare, 2005)

\section{Earth (the Great House of Mankind, Identification with the Homeland)}

Is in Kadare's poetry the land identified with the homeland? We can say that in many cases in his poetry the land also emerges as a homeland, but it also emerges as a concrete land on which it travels, walks and works on it. Kadare has a very clear concept of land, even when it is used as a concept equivalent to the homeland, and when it is used to connect the common man with the land, not only as a homeland, but first and foremost as a part of life. his.

Earth in terms of the planets has an interesting use in the poem "The Peoples' Time", where we have a confrontation of two contemporary oppositions of the ruling powers of the superpowers and the efforts of the peoples to be free and to dominate their planet-earth., which really belongs to them. After three rather striking metaphors, Kadare exaggerates the causal links with time and earth, as in the verses:

Horrible horns and cries of cobia

On earth they set the law of the beast;

However it was people's time

And this planet of former people. (Ismail Kadare, 1976)

The land is also used in the simple sense, just as a piece of land, but also in the equivalent sense of land and homeland, when it takes other meanings or when used as an equivocal, as in the poem "Kosovo", where the land sign has two important meanings as land in the general sense of the planet, but also as homeland designated land of Kosovo, as in verses:

But the broad back of your land runs down,

It looks and disappears grimly between the cavities and cloud abyss. (Ismail Kadare, 2005)

In the ambiguous sense the function of the earth sign is also used in the poetry "Clouds", which is a poem with tragic and ballad notes, in which case the secondary function is given by the vatan, which in this case is equal to the land of the homeland. Poetry is composed of three dystics, as follows:

Between the mountains further eastward

As a soldier fell under cruel bullets.

Not even a cross was put on them, they were not put on the ground

Neither her mother nor her sister were on her head.

Except the clouds that came from far away

We saw him and recognized him and wept. (Ibidem, p. 38.)

Alienation of mud land, mud-like land, land that is no longer land - homeland, but because of treachery only land - mud, and the return of homeland to a widow, but because of treason humiliation by treachery, are the figures that Kadare uses by using the land mark in the anthology poetry "The Escape of Moses Golem" in the following verses:

The earth is just mud,

But no longer home.

Earth as a widow

Took away any jewelry. 


\section{Homeland died, clay remained}

Under the black knock. (Ismail Kadare, 1978)

A poem that is quite characteristic of the functional use of the earth sign in interaction with the sky sign is the poem "Cooling the Earth". The following verses:

The elders say: it is wintering on earth, not in heaven

Beware of winter on earth. (Ismail Kadare, 1990)

Even in the poem "The First Parachutists" the signs of the earth and the sky are used in an efficient way, as in the verse:

Four girls will go down to earth, from the floors of heaven.( Ismail Kadare, 1978)

\section{Conclusion}

Certainly the treatment of cosmic signs in Ismail Kadare's poetry could be expanded with some other cosmic signs, but we have not expanded because other signs, besides those we have dealt with, in Kadare's poetry do not show any significant relevance. .

But, in summary, we can conclude that the cosmic signs, which we have considered most prominent in Kadare's poetry, which, in addition to being significant and lexical signs, constitute symbols, are:

- the sun, which begins with light, as a pillar of life, but also as a symbol, which brings warmth and vitality;

- the moon, as a contemplative and guardian of love, is not infrequently presented as beauty, sometimes diminished by the litotes - the little moon;

- the star, in most cases as a sign of the cosmos, but also as a symbol, guide;

- the sky, takes a broad, complete picture, also presented as a mass, as a shape, as a width, as a cosmic infinity.

- the land, the place where we are human, the great house of mankind, the place that is identified with the homeland.

\section{References}

Osvald, D., \& Tzvetan, T. (1984). (Encyclopedic Dictionary of Lecture Sciences) "Rilindja”, Prishtinë, p. 143.

Ismail, K. (1978). Motive me diell (Sunni motives), "Rilindja”, Prishtina, 45.

Ismail, K. (1976). Koha (Time), "Naim Frashëri”, Tiranë, p. 33.

Ismail, K. (1990). Ftesë në studio (Invitation to the studio), "Naim Frashëri”, Tirana, p. 12.

Ismail, K. (1957). Ëndërrimet... (Dreaming...), Ndërmarrja Shtetërore e Botimeve, Tirana, p. 22.

Ismail, K. (1957). Koha (Time), op. cit., p. 63.

Ismail, K. (1957). Ëndërrimet... (Dreaming...), op. cit., p. 22.

Ismail, K. (1954). Frymëzimet djaloshare, f. 52-53.

Ismail, K., \& Ftesë në studio (1990). (Invitation to the studio), op. cit., p. 14.

Ismail K. (1957). Ëndërrimet... (Dreaming...), op. cit., p. 13.

Ismail K. (1961). (My century), "Naim Frashëri”, Tirana, p. 7.

Ismail K. (1957). Ëndërrimet... (Dreaming...), p. 7.

Ismail K. (1961). Shekulli im (My century), op. cit., p. 31.

Ismail K. (2005). (Without form is heaven), "Onufri”, Tirana, 2005, p. 17; Ismail Kadare, Vepra, vëllimi 7 (Works, volume 7), "Onufri”, Tirana, 2008, p. 43.

Ismail K. (1957). Ëndërrimet... (Dreaming...), op. cit., p. 5.

Ismail K. (1990). (Invitation to the studio), op. cit., p. 38.

Ismail K. (2005). (Without form is heaven), op. cit., p. 16.

Ismail K. (1961). Shekulli im (My century), op.cit., p. 10.

Ismail K. (1957). Ëndërrimet... (Dreaming...), op. cit., f. 27.

Ismail K. (1964). (Why are these mountains), "Naim Frashëri”, Tirana, p. 26.

Ismail K. (2005) (Works, volume 7), p. 220. 
Isamil K. (1976). Koha (Time), op. cit., p. 3.

Ismail K. (2005). Vepra, (Works, volume 7), op. cit., p. 220.

Ismail K. (1978). Motive me diell (Sunni motives), op. cit., p. 130.

Ismail K. (1990). Ftesë në studio (Invitation to the studio), op. cit., p. 33.

Ismail K. (1978). Motive me diell (Sunni motives), op. cit., p. 33.

\section{Notes}

Note 1. Ferdinand De Saussure, Kurs i Gjuhësisë së Përgjithshme (General Linguistics Course), “Dituria”, Tiranë, 2002.

Note 2. Ismail Kadare, Pa formë është qielli (Without form is heaven), op. cit. The foreword to this selective compilation was written by the poet scholar Sadik Bejko, who, while qualifying the title of this book as an emblematic title, nevertheless gives the inconsistent conclusion that Kadare's comparison to the sky of Tirana with the brain and mind of one the idiot is a hint at socialism. This is in no way due to the fact that despite Kadare's political shutters, which of course have influenced his artistic, literary, publicist and aesthetic shutters, only the Kadare poetry and prose writings of that time have been taken into account. , could not believe such an attitude. Even his subsequent social engagement contradicts Bejko's conclusions about Kadare's "antisocialism" at that time. All the more so when the poetry "Autumn Tyrant", which is a beautiful and brilliant picture of autumn, beautifully expressed through the anthological verses used by Kadare and which in no way has any foresight or allusion to the socialist heaven of Tirana, it was written in 1957. However, it is the time when Kadare struggles to free himself from the political poetry he has cultivated at least, naturally as a result of the influences of social currents or even as part of his ideal, whether unfinished, be it unfulfilled. After all, the operation, that is to say such findings as Sadik Bejko attempts, are not only unstable but also counterproductive.

\section{Copyrights}

Copyright for this article is retained by the author(s), with first publication rights granted to the journal.

This is an open-access article distributed under the terms and conditions of the Creative Commons Attribution license (http://creativecommons.org/licenses/by/4.0/). 